\title{
Comparative Study between Synoptophore and Cover Test with Prisms at Far Vision
}

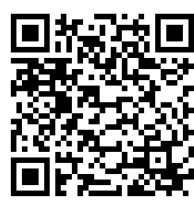

\author{
Dra D Fdez-Agrafojo*, Martín Enrile P, Morales Ruiz H and Soler Valls M \\ Teknon Medical Center, Spain
}

Submission: November 11, 2016; Published: January 16, 2017

*Corresponding author: Dra D Fdez-Agrafojo, Teknon Medical Center, Barcelona, Spain, Tel: 933933156; Email: fdezagrafojo@dr.teknon.es

\section{Abstract}

Objective: Based on the measurement of strabismus angle with prisms at far vision, which is the most widely used method, we compare it with the measurement performed with synoptophore. We evaluate which factors influence the measurement with synoptophore and with Cover Test with prisms at far vision.

Method: In a sample of 64 patients with a mean age of 27.6 years, we consider two common clinical methods of measuring the angle of ocular deviation: synoptophore and cover test with prisms. Given the differences, we find between the measurement of the angle of ocular deviation and what factors may influence the variability with both methods.

Results: Comparing the measured deviation angle in 64 patients with both methods at far vision, we found a statistically significant difference, with an average of 1,844 prism dioptres. If we compare both methods in esotropia or exotropia, in the 43 patients with esotropia found a statistically significant difference (mean difference $2.721 \mathrm{Dp}$ ). On the other hand, in the 21 patients with exotropia there was no a statistically significant difference (mean difference $0.048 \mathrm{Dp}$.). Considering gender, 35 men of the sample, we find statistically significant differences (mean difference 2.171Dp), and women, 29 patients of the sample, we also found statistically significant differences (mean difference 1.448Dp).

Conclusion: In esotropia we find that there are statistically significant differences in cover test with prisms at far vision. On the other hand, in exotropia we don't find statistically significant differences. In both the groups of patients with previous strabismus surgery and non-surgery there are no statistically significant differences. The fact that we find a greater deflection angle with the synoptophore at convergent strabismus confirms the ability of dissociation.

Keywords: Synoptophore; Cover test; Dissociate prism dioptre; Strabismus; Exotropia; Esotropia

\section{Introduction}

The stereoscope invented by Charles Wheatstone in 1830 used for oculomotoras and sensory evaluation. Its main use is to assess and treat strabismus, also used in vision therapy for the treatment of amblyopia [1]. It simulates far vision conditions and presents separate images for each eye. It studies oculomotoras and sensory capabilities mainly in strabismus patients [2]. Although the measure of the deviation angle is usually performed with prism bar or loose prisms, it is worth considering the synoptophore, given its characteristics.

Compared with measurement with cover test (CT) and prisms, in synoptophore we obtain:

A. A higher value of deviation as it is more dissociating.

B. More simplicity and comfort in the measurement of the 9 positions of gaze thanks to its mechanical structure.
C. The values are more reproducible, making it easier for monitoring the case.

D. More accurate values in high-angle strabismus, since in these cases the measure is not performed in leaps.

E. More objective measurement.

\section{Materials and Methods}

In a sample of 64 patients, with a mean age of 27.6 years, we consider two common clinical methods of measuring the angle of ocular deviation: synoptophore and Cover Test with prisms at far vision. We study which differences we find between both methods and what factors may influence the variability of the results. We studied the influence of factors such as the direction of the horizontal deviation (esotropia/ exotropia), if they had vertical deviation or some sort of alphabetical syndrome, if they 
had undergone strabismus surgery previously and finally the patient's gender.

\section{Results}

Comparing the measurement of the deviation angle in 64 patients with synoptophore and cover test with prisms at far vision we find:

\section{Comparison in factors (Table 1):}

Table 1: $P=0.0001$.

\begin{tabular}{|c|c|c|c|}
\hline & $\mathbf{n}$ & $\operatorname{MEAN}(\boldsymbol{\Delta})$ & $\mathbf{S D}$ \\
\hline Synoptophore & 64 & 5,484 & 20,739 \\
\hline Ct prisms & 64 & 3,641 & 19,353 \\
\hline Difference & 64 & 1,844 & 3,578 \\
\hline
\end{tabular}

\section{Type of deviation}

A. Esotropia: $\mathrm{P}<0,0001$ (Table 2)

Table 2: Esotropia $\mathrm{P}<0,0001$.

\begin{tabular}{|c|c|c|c|}
\hline & $\mathbf{n}$ & $\operatorname{MEAN}(\boldsymbol{\Delta})$ & SD \\
\hline Synoptophore & 43 & 17,465 & 9,888 \\
\hline Ct prisms & 43 & 14,744 & 9,000 \\
\hline Difference & 43 & 2,721 & 3,541 \\
\hline
\end{tabular}

B. Exotropia: $\mathrm{P}=0,9426$ (Table 3)

Table 3: Exotropia $P=0,9426$.

\begin{tabular}{|c|c|c|c|}
\hline & $\mathbf{n}$ & $\operatorname{MEAN}(\boldsymbol{\Delta})$ & SD \\
\hline Synoptophore & 23 & 18,913 & 10,553 \\
\hline Ct prisms & 23 & 16,696 & 9,888 \\
\hline Difference & 23 & 2,217 & 4,145 \\
\hline
\end{tabular}

\section{History of strabismus surgery}

A. With previous surgery: $\mathrm{P}=0,0176$ (Table 4)

Table 4: With previous surgery $\mathrm{P}=0,0176$.

\begin{tabular}{|c|c|c|c|}
\hline & n & MEAN $(\boldsymbol{\Delta})$ & SD \\
\hline Synoptophore & 23 & 18,913 & 10,553 \\
\hline Ct prisms & 23 & 16,696 & 9,888 \\
\hline Difference & 23 & 2,217 & 4,145 \\
\hline
\end{tabular}

B. Without previous surgery: $\mathrm{P}=0,0036$ (Table 5)

Table 5: Without previous surgery $\mathrm{P}=0,0036$

\begin{tabular}{|c|c|c|c|}
\hline & $\mathbf{n}$ & MEAN $(\boldsymbol{\Delta})$ & SD \\
\hline Synoptophore & 41 & 17,463 & 12,085 \\
\hline Ct prisms & 41 & 15,878 & 11,775 \\
\hline Difference & 41 & 1,585 & 3,279 \\
\hline
\end{tabular}

\section{With previous surgery}

A. Esotropia: $\mathrm{P}=0,0104$ (Table 6)

Table 6: Esotropia $\mathrm{P}=0,0104$.

\begin{tabular}{|c|c|c|c|}
\hline & n & MEAN ( $\boldsymbol{\Delta})$ & SD \\
\hline Synoptophore & 14 & 17,786 & 10,334 \\
\hline Ct prisms & 14 & 14,214 & 8,210 \\
\hline Difference & 14 & 3,571 & 4,467 \\
\hline
\end{tabular}

B. Exotropia: $\mathrm{P}=0,9001$ (Table 7)

Table 7: Exotropia $\mathrm{P}=0,9001$

\begin{tabular}{|c|c|c|c|}
\hline & n & MEAN $(\boldsymbol{\Delta})$ & SD \\
\hline synoptophore & 9 & 20,667 & 11,269 \\
\hline ct prisms & 9 & 20,556 & 11,479 \\
\hline difference & 9 & 0,111 & 2,571 \\
\hline
\end{tabular}

\section{Without previous surgery}

A. Esotropia: $\mathrm{P}=0,0003$ (Table 8)

Table 8: Esotropia $P=0,0003$.

\begin{tabular}{|c|c|c|c|}
\hline & $\mathbf{n}$ & MEAN $(\boldsymbol{\Delta})$ & SD \\
\hline Synoptophore & 29 & 17,310 & 9,849 \\
\hline Ct prisms & 29 & 15,000 & 9,487 \\
\hline Difference & 29 & 2,310 & 3,001 \\
\hline
\end{tabular}

B. Exotropia: $\mathrm{P}=0,8675$ (Table 9)

Table 9: Exotropia $\mathrm{P}=0,8675$.

\begin{tabular}{|c|c|c|c|}
\hline & $\mathbf{n}$ & MEDIA $(\boldsymbol{\Delta})$ & SD \\
\hline Sinoftoforo & 12 & 17,833 & 16,851 \\
\hline Ct prismas & 12 & 18,000 & 16,376 \\
\hline Diferencial & 12 & 0,167 & 3,380 \\
\hline
\end{tabular}

\section{Gender}

A. Male: $\mathrm{P}=0,0017$ (Table 10)

Table 10: Male $P=0,0017$.

\begin{tabular}{|c|c|c|c|}
\hline & $\mathbf{n}$ & MEAN $(\boldsymbol{\Delta})$ & SD \\
\hline Synoptophore & 35 & 4,229 & 24,288 \\
\hline Ct prisms & 35 & 2,057 & 22,601 \\
\hline Difference & 35 & 2,171 & 3,761 \\
\hline
\end{tabular}

B. Female: $\mathrm{P}=0,0280$ (Table 11)

Table 11: Female $P=0,0280$.

\begin{tabular}{|c|c|c|c|}
\hline & $\mathbf{n}$ & MEAN $(\boldsymbol{\Delta})$ & SD \\
\hline Synoptophore & 29 & 7,000 & 15,721 \\
\hline Ct prisms & 29 & 5,552 & 14,681 \\
\hline Difference & 29 & 1,448 & 3,366 \\
\hline
\end{tabular}

We also assessed whether other factors such as vertical deviations or alphabetic syndromes could influence the comparison. Given the low percentage of patients who showed vertical strabismus or alphabetical syndrome, comparative under these factors was dismissed [3-8]. 


\section{Discussion}

Despite significant statistical differences in convergent strabismus, in regular motor examination we always include the measurement with synoptophore as well as the measurement with prism at far vision.

We consider that the greater accommodative capability that convergent strabismus present, both at far and near vision, allows the synoptophore, as being more dissociating, to find greater deviation angles. We believe that although with synoptophore there is a risk of causing greater dissociation in some type of strabismus, for us its use for justified the measure, because it is more accurate, objective and reliable. Anyway we still complete the study with the measurement with prisms. In our protocol for measuring ocular alignment we consider the measurement with synoptophore, objectively, a complementary study to consider.

\section{Conclusion}

In esotropia we found that there was statistically significant differences respect to the measurement at distance with prisms at far vision. In exotropia we didn't find statistically significant differences. Both in patients with previous strabismus surgery and non-surgery there are statistically significant differences. The fact that we find a greater deflection angle with the synoptophore at convergent strabismus confirms the ability of dissociation that we initially suspected occurs with Synoptophore [9-12].

\section{References}

1. Saona Santos CL Sinoptòfor (2012) Les seves funcions per al diagnòstic de desequilibris oculomotors. Quaderns Científics del Col legi Oficial d’òptics de Catalunya.
2. Peñalba BA (2009) Procedimientos clínicos para la evaluación de la visión binocular. In: Netbiblo La Coruña (Ed.).

3. Susan A Cotter, Robert P Rutstein, Martin S Cogen, Kent M Daum, Rochelle L Mozlin, et al. (1995) Clinical Uses of Prism. Mosby, St. Louis Missouri, USA.

4. Zamora M (1988) Sharp M and Dohme Iniciación a la Estrabología. Madrid, Spain.

5. Prieto- Diaz J, y Souza- Dias C (2005) Estrabismo. Julio Ed Jims.

6. Bagolini B (1957) Presentazione di una sbarra di filtri a densita scalare assorbenti i raggi luminosi. Boll Ocul 38: 638.

7. Burian HM, Von Noorden GK (1980) Binocular vision and ocular motility. Theory and management of strabismus ( $\left.2^{\text {nd }} e d n\right)$, CV Mosby, St. Louis, USA.

8. Flynn MD, McKenney S, Rosenhouse M (1975) Management of Intermitent Exotropia orthopties past, present, future transactions of third International Orthoptic Congress, Boston, USA, p. 1-3.

9. Inatomi A (1957) Observations on the visual functions in strabismus. Report II. Observations on retinal suppression and correspondence. Acta So Ophthal Jap 61(2): 1529-1543.

10. Krzystkowa K, Pajakowa JY (1972) Citado por Burian HMy Von Noorden GK Binocular vision and ocular motility. Theory and management of strabismus. CV Mosby, St. Louis, USA.

11. Lang (1981) Strabisme Diagnostic, formes cliniques traitement. Hans Huber, Berne, p. 65,

12. Veronneau- Troutman (1965) Prisms as ant orthoptic tool in the Management of Primary Exotropia. Orthoptics, past, present, future. Editors Sally Moore, Mein and Stockbriedge. Transactions of the third International Orthoptic Congress, Boston, USA, 1(3): 195-201.
Your next submission with Juniper Publishers will reach you the below assets

- Quality Editorial service

- Swift Peer Review

- Reprints availability

- E-prints Service

- Manuscript Podcast for convenient understanding

- Global attainment for your research

- Manuscript accessibility in different formats (Pdf, E-pub, Full Text, Audio)

- Unceasing customer service

Track the below URL for one-step submission https://juniperpublishers.com/online-submission.php 